\title{
Facebook's power to mobilize fans in the electoral campaign. Case Study: 2019 European Parliamentary Elections in Romania
}

\author{
Assist. Prof. PhD. Tănase Tasențe \\ "Ovidius" University of Constanta, Romania \\ office@pluscommunication.eu
}

\begin{abstract}
Since 2008, when Barack Obama won the United States election thanks to Facebook, that success model has been improved year by year, and at present Social Media has become the main channel of communication in electoral campaigns, ahead of traditional media (TV, radio, newspapers). The novelty of this communication mechanism can be described by decentralizing the communication to social groups of online opinion leaders and eliminating the horizontal dimension, in which mass-media and political actors played fundamental roles in disseminating the political message to the public. In Social Media, the message is decentralized from source (political actor's Facebook page) by some ordinary users, which in time become influential leaders in the virtual environment. Moreover, political parties that managed to mobilize most fans to disseminate political information in their social groups (strong and weak links) managed to achieve better electoral scores. Our study focused on analyzing the campaign on Facebook in the electoral campaign of the main three parties in Romania, which won the most mandates in the European Parliament: the National Liberal Party (yellow), the Social Democratic Party (red) and the Union "Save Romania" (blue). The election campaign took place from 27 April 2019 to 25 May 2019 and the voting day was on 26 May 2019.
\end{abstract}

Keywords. Facebook election, European Parliamentary Elections, Social Democratic Party, Union Save Romania, National Liberal Party

\section{Introduction}

Along with the development of the Facebook, also the principles of the media communication have changed. If in traditional media the feedback was delayed or absent, the entire communication focusing on "broadcast" or "unidirectional communication", in Social Media Era, the SNSs are working on principles such as "social interaction", "multidirectional communication" and "the public impose the media agenda".

The novelty of this communication mechanism can be described by decentralizing the communication to social groups of online opinion leaders and eliminating the horizontal dimension, in which mass-media and political actors played fundamental roles in disseminating the political message to the public. In Social Media, the message is decentralized from source (political actor's Facebook page) by some ordinary users, which in time become influential leaders in the virtual environment.

The political message is discussed in social groups of the "online political citizens" (Institute for Politics, Democracy and Internet, 2004) and there are created through 
interpersonal communication, standard opinions, to which each social groups' members will join. After the deliberation of the political message in social groups, some users choose to become members (fans) of the source message (political actor's Facebook page), and thus the database of the potential users like "online political citizens" (online opinion leaders), who will redistribute political message to still unreached social groups, will increase.

\section{Importance of strong and weak links in Social Media}

As SNSs become more and more powerful and complex, classical communication theories have been adapted to the new principles of Social Media. Mark Granovetter (1973) proposed a theory of communication, The Strength of Weak Ties, which other researchers of the Social Media phenomenon can apply to establish connections between the types of social connections in the online environment.

Granovetter's theory refers to the relationships between structures, the intensity of social ties, and the dissemination of information in offline social networks. It has characterized in two ways the social ties: its power and its position in social networks. In one direction, social ties are characterized precisely by their power, corroborated with the time spent together, intimacy and the emotional intensity of a relationship. While strong ties relate to relationships with friends and relatives, weak connections refer to distant knowledge. On the other hand, a social connection can also be characterized by the position it has on social networks.

A link may be within a social group, there may be links between groups, there may be intermediate links, or there may be situations between entities belonging to a group and entities that are not affiliated with any group.
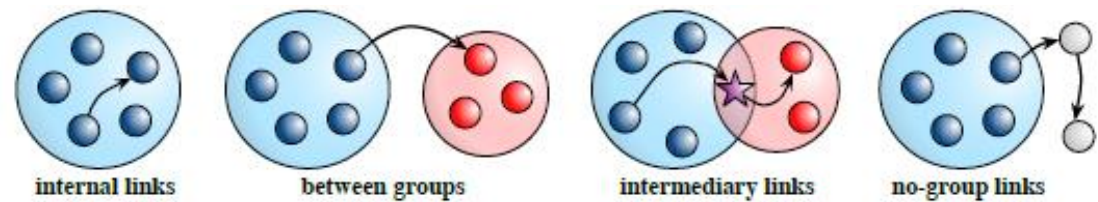

Figure 1 - Different types of links taking into account the position in the social group structure: internal links, group links, intermediate links and groupless links

Granovetter's theory is based on the idea that weak links act as a bridge between groups and are very important for disseminating new information through the social network. Strong links are presumed to be located within groups among actors with many friends in common.

Translating this theory into analyzing communication through social networks, we find that SNSs have generated secondary groups of a different nature than we know them in traditional social networks, namely groups and virtual communities, aggregated according to the criterion of individual interests. As a comparison, virtual groups no longer take into account indicators such as spatial proximity, age difference or socio-professional membership, as is the case with offline social networks.

\section{European Parliamentary Elections in Romania - Facebook analysis}

\subsection{Research objectives}

O1: Analyzing the Key Performance Indicators (KPIs) that facilitate Social Media Communication in the 2019 European Parliamentary Elections in Romania. 
O2: Identify and analyze messages that generate high engagement from users

O3: Analyzing the dominant reactions generated by the online audience

\subsection{Methodology}

To achieve the research objectives, we will use both quantitative and qualitative methods. Thus, we analyzed the campaign of Facebook communication in the electoral campaign of the main three parties in Romania, who obtained the most mandates in the European Parliament: the National Liberal Party (yellow), the Social Democratic Party (red) and the Union "Save Romania" (blue). The election campaign took place from 27 April 2019 to 25 May 2019 and the voting day was on 26 May 2019.

\subsection{Centralization and data analysis}

\section{Political party fans and demographic profile of Facebook users in Romania}

Most Facebook fans have the National Liberal Party $(293,677)$, followed by Union Save Romania $(126,466)$ and the Social Democrat Party $(86,541)$. Thus, we observe that the National Liberal Party has 2.32 times more fans than the Union Save Romania and 3.39 times more fans than the Social Democratic Party.

According to Facebrands.ro, there are about 9,600,000 Facebook users in Romania, which means that 3,06\% of the users are fans of the National Liberal Party, 1,32\% are fans of Save the Romania Union, and 0,90\% are fans of the Social Democratic Party. Moreover, from a demographic point of view, 50\% of Facebook users in Romania are men and 50\% are women. Predominant age categories are: $25-34$ (26.83\%), followed by $18-24$ (21.47\%), 35-44 $(21.15 \%)$. At the opposite end, we find age categories: 45-54 (12.63\%), 55-64 (6.16\%) and $65+(2.53 \%)$.

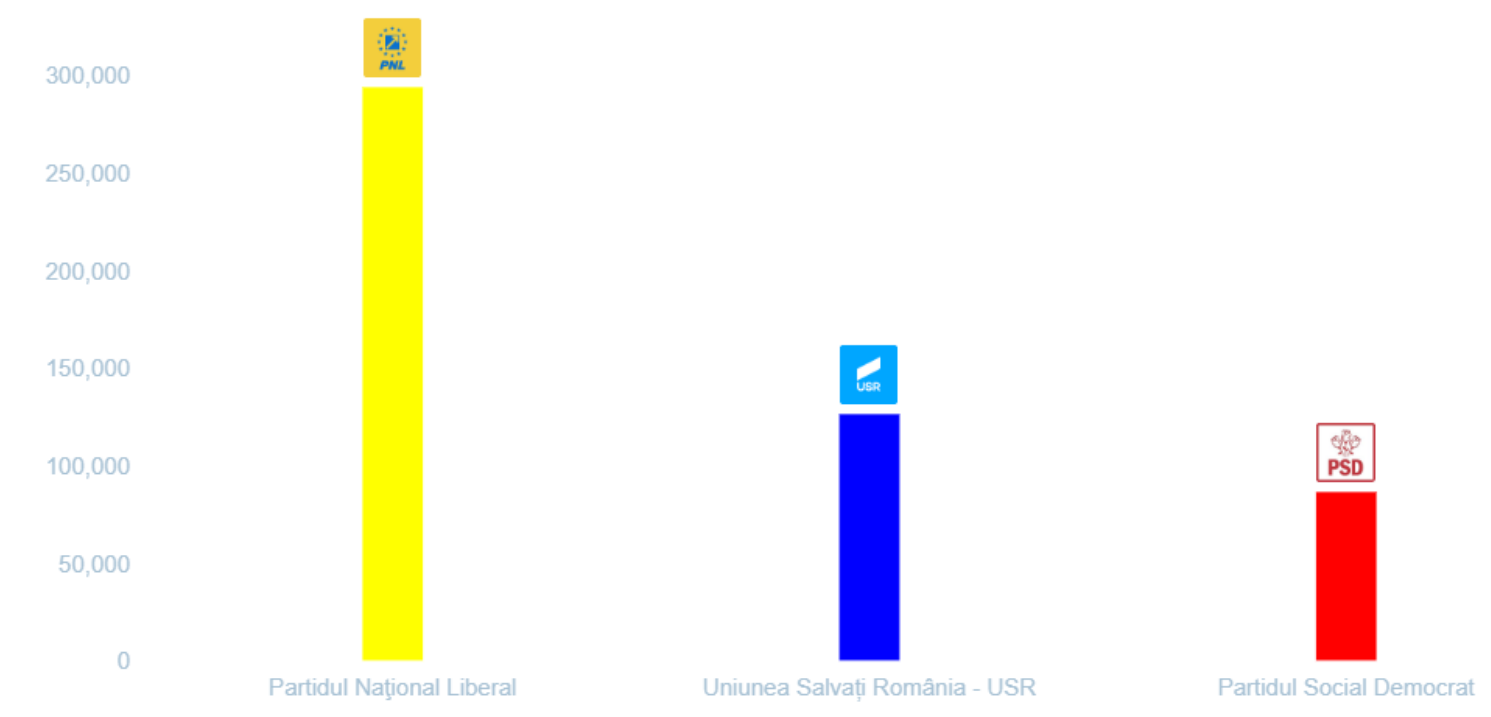

Figure 2 - The evolution of the number of fans of the Romanian parties (27 th of April, 2019 $25^{\text {th }}$ of May, 2019)

The engagement rate of the fans and the decentralization of political information in their social groups

The fans of the National Liberal Party were the most active in commenting on and disseminating political information provided by the party, $72.9 \%$ of all reactions, comments and shares in the election campaign were generated by National Liberal Party fans. On the 
other hand, USR fans generated an interaction rate of $20.8 \%$ of the total interactions generated by the three monitored parties, and the Social Democratic Party, 6.3\%.

More than that, during the election campaign, the online audience generated 979,000 responses, comments and shares on the National Liberal Party's website (a 12\% engagement rate). On the other hand, there were 279,000 responses, comments and shares on the USR page ( $7.8 \%$ - engagement rate), and on the Social Democratic Party page - 85.000 (3.4\% engagement rate).

Political information has also been disseminated to other social groups (users who were not necessarily the fans of a political party), this indicator being extremely important because it can send information to nodes of the network that are still unaccounted for by parties. Through this mechanism, political information reaches from the fan to its strong links so that the credibility of information grows considerably. And in terms of disseminating political information in Social Media, the National Liberal Party is leading the online communication campaign with 105,000 shares. On the other hand, the information on the USR page has received 48,000 shares, and those on the Social Democratic Party page, 13,000. From the chart below, we can see that at the start of the campaign the highest engagement rate was held by USR (11\%), but the interest of fans declined considerably by the end of the campaign when the engagement rate reached 5.4\%. On the other hand, we can see that National Liberal Party fans were more active in the Social Media, generating a 19\% peak on 13 May 2019, but at the end of the election, this rate dropped to 9.8 percent. Social Democratic Party failed to mobilize fans online, the rate of engagement was at the beginning of the campaign $1.1 \%$ experienced an increase of $6.8 \%$ (on May 6, 2019), and by the end of the campaign, only $2 \%$.

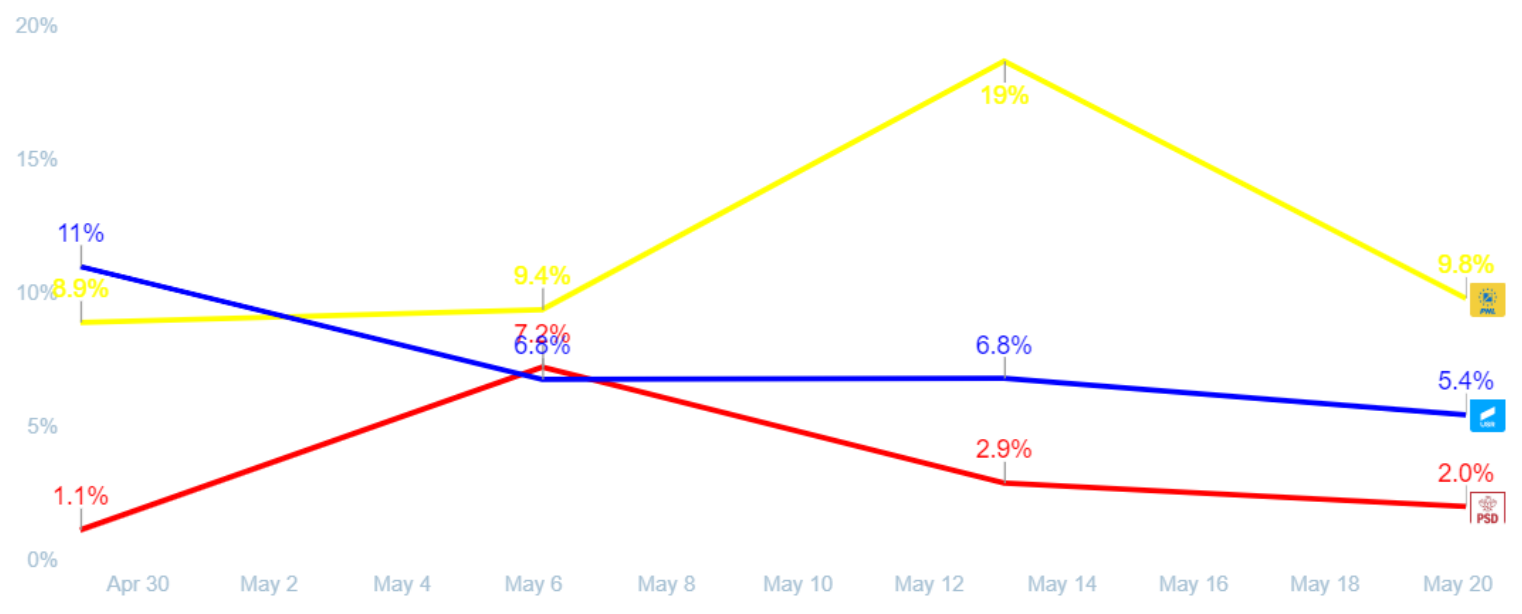

Figure 3 - The evolution of the engagement rate during the election campaign

\section{Predominant emotions generated by the political party posts}

Regarding the number of posts, the National Liberal Party's communication specialists are the most active, publishing 222 posts ( 7.66 posts per day) during the electoral campaign. On the other side 153 posts (5.28 posts per day) were published on the USR page, and on the Social Democratic Party page, 37 (1.28 posts per day). Posts on the National Liberal Party's website generated, in a very large proportion, haha reactions (10245), followed by likes (3241), love (2249) and anger (1854). Articles published by USR on the Facebook 
page generated reactions of anger (1660) and like (1057), and those published by the Social Democrat Party, like reactions (1338), anger (795) and haha (599).

\section{Posts with the highest engagement rate The National Liberal Party}

On May 13, 2019, the National Liberal Party said it increased child allowances, trying to generate emotions among mothers (a major category on Facebook). The post generated 50,496 likes, 1288 love, 2126 haha, 265 wow, 93 sad, 451 angry, 4006 comments and 3889 shares.

On May 19, 2019, the National Liberal Party publishes a statement by the President of Romania, Klaus Iohannis: "Dear Romanians, because I can not vote for you at the Referendum, give a strong, clear, strong reply to this failed government of the Social Democratic Party. Release Romania, I expect you all to vote on May 26. For Romania, for the future of Romania". The post generated 47122 likes, 1530 love, 755 haha, 79 wow, 152 sad, 2043 angry, 3016 comments and 4070 shares.

On May 20, 2019, the National Liberal Party publishes the statement of candidate Rares Bogdan, who is on the first position on the party's list: "Our lives, of the Romanians, is the sum of the choices we make daily. Romania has a great need today to involve each of us. I call you on May 26 to vote to decide what kind of country we want to raise our children! Vote PNL!". The post generated 37,328 likes, 705 love, 1215 haha, 86 wow, 93 sad, 1639 angry, 3913 comments and 4193 shares.

On May 19, 2019, the National Liberal Party publishes a new statement by candidate Rares Bogdan: "We want to do what the PSD did not do with its allies, we want to increase the subsidy in agriculture to the European average. we abolish all the bureaucracy that blocks the absorption of European funds: we have sixty-four conditionalities and Poland has six. We want in every city in Romania, Alexandria, Slatina, Braila, Galati, Vaslui, to live like in Cluj, Alba, Suceava, Arad, Oradea, Deva, Timisoara, so that the Romanians will no longer cross the border". The post generated 33,715 likes, 709 love, 1437 haha, 98 wow, 93 sets, 1329 angry, 3913 comments and 3267 shares.

On May 19, 2019, the National Liberal Party posted an electoral video, adding: "In Victory Square, 50,000 people have demonstrated for change. They have demonstrated for a just Romania, for an honest Romania, for a Romania of correct men". The video, which was watched 1,111,528 times, generated 29,326 likes, 1150 love, 861 haha, 135 wow, 92 sad, 411 angry, 3,402 comments and 7,235 shares.

\section{The Social Democratic Party}

The top 3 posts with the highest engagement rate are videos featuring demonstrations by party supporters in Bucharest, and a show with party president Liviu Dragnea. None of the videos contain a message and have a very long length between 45 and 54 minutes. These were posted on May 9, May 11, and May 12, 2019. They were watched on an average of 95,646 times, generating between 1205 and 1412 likes, between 184 and 250 love, between 88 and 164 haha, between 179 and 958 angry, between 746 and 4718 comments and between 473 and 656 shares.

On May 10, 2019, the Social Democratic Party published a photo of a party's electoral event, with the following message: "Thank you all for your support! Romania deserves more respect! Vote PSD on May 26th!" This post has generated 2,795 likes, 130 love, 251 haha, 3 wow, 8 sad, 179 angry, 746 comments and 803 shares. 
On May 12, 2019, the Social Democrat Party published a photo of a vegetable stall on its Facebook page, with the following message: "Healthy food for our children! The success of the tomato program, where tens of thousands of households received as much as 3000 euros for each 1000 square meters of cultivated greenhouse, has led us to support even more Romanian producers. We have increased the garlic subsidy and are ready to launch the programs for peppers, eggplants and cucumbers. We develop national vegetable-growing, we provide tasty and healthy Romanian food for us and our children" The post generated 2,653 likes, 80 love, 208 haha, 5 wow, 1 sad, 80 angry, 432 comments and 745 shares.

\section{The Union Save Romania}

On May 15, 2019, the USR attacks the Central Electoral Bureau's decision: "The decision of the Central Election Bureau to ask questions at the 26 May referendum on separate ballot papers is unjustified and could hinder the electoral process. the first effect of the measure to separate questions is the increase in costs, both with the printing of ballots and logistics. Another effect could be the validation of the referendum for just one of the questions, a convenient situation for the PSD-ALDE coalition. This is not the first time that the PSD and the ALDE are trying to hinder the holding of a referendum on Justice. They wanted first separate polling stations. Then they wanted to go to the validation threshold. Now, it separates the questions from the referendum. Romanians should not be discouraged, but they should be encouraged to come to the polls and to express their opinion on amnesty and pardon for acts of corruption, namely amending criminal legislation through emergency ordinances and the right of other constitutional authorities to refer to the Court Constitutional Treaty of Romania. The political class has the duty to listen to the voice of the people and to make decisions in the interests of it, not in the personal interest. Vote on May 26 at the European Parliamentary elections and at the referendum!". The post generated 9,764 likes, 117 love, 310 haha, 57 wow, 33 sad, 503 angry, 522 comments and 2378 shares.

On April 27, 2019, USR published a post accusing the PSD-ALDE Alliance that it did nothing for farmers. "PSD-ALDE has done nothing for small farmers. For decades, farmers 'work has been mocked by the mafia of intermediaries and the authorities' complicity. Since being the Minister of Agriculture, Petre Daea has done nothing to remedy the situation of small farmers so that they can live a decent living from what they produce. Until they sell in the markets, Romanian vegetables and fruits are going through three or even four hands, and farmers get ridiculous sums for their work. During the summer, the cucumber kilo is sold by the farmer with 50 bani / kilogram. Farmers deserve to have real support in the Ministry of Agriculture, a support that allows them access to markets and income to be in line with the work they make, not a minister who tells stories about cormorants and swimming pools in front of the European Parliament. Without thievery we get far. Enter www.usrplus.ro and find the 2020 USR PLUS Alliance Plan for Romania!”. The post generated 6.256 likes, 46 loves, 213 haha, 42 wow, 342 sad, 1,209 angry, 1,977 comments and 1,679 shares.

On May 1, 2019, USR publishes another attack on the PSD-ALDE Alliance. "Romania is not, and it was not, a poor country. It is a country with poor people who have been held in the same way as a thieving octopus, corruption and nepotism that has patched state institutions at all levels. Without thievery we have money for hospitals. Every year, the Health Minister has more than EUR 250 million available for investment, but the PSD has not built any hospital from scratch in all the governments it has had. In 2016, the Cioloş government unlocked the EU hospitals' regional hospital projects that were abandoned by the PSD Government as soon as it took over the government. Why? Because it was hard to steal them. Without thievery, we finish the highways. In the last 30 years, the governments of 
Romania have not been able to build a single highway linking the historic provinces, although it had European money available for that, all they had to do was ask them. However, the governments of Romania preferred not to use them because in Europe $1 \mathrm{Km}$ has 1,000 meters or 800 meters in the Dragnea Teleorman. Without thievery, we can have better schools. From 2008 to the present, although the law says school principals have to be called by competition, this has not happened. In 2016, when the Cioloş government tried to organize the first contest for school heads, PSD reacted vehemently and blocked the initiative in Parliament because they did not want to lose control of schools to steal. We do not have modern hospitals because they steal. We do not have highways because they steal. We do not have quality education because they steal". The post generated 5,474 likes, 41 love, 105 haha, 21 wow, 243 sad, 1,081 angry, 1,137 comments and 1,620 shares.

On May 4, 2019, USR posted an attack on candidate no. 1 on the PSD list: "Rovana Plumb opens the PSD list for MEPs, although she has not seen anything in more than 15 years of public office. The PSD demonstrates that "Patriots in Europe" are empty words. While in the Ponta government, Rovana Plumb avoided paying taxes to the Romanian state by registering a luxury car in Bulgaria. A loyal soldier to any boss who has given her a job, Rovana Plumb was dropped by Belina's investigation by the vote of PSD-ALDE lawmakers who opposed the lifting of her immunity. Thus, the Justice can no longer pronounce on the possible crimes committed by Rovana Plumb. PSD comes in 2019 with the same obsolete recipes. Sinecists, eternal candidates for public positions without achievements and unprepared people. The 2020 Alliance USR PLUS will send to the European Parliament experienced, honest and competent people ready to implement a comprehensive program that will bring Romania's welfare". The post generated 4,827 likes, 55 love, 348 haha, 52 wow, $110 \mathrm{sad}, 1,514$ angry, 1,190 comments and 1,156 shares.

On 2 May 2019, USR again attacked the PSD-ALDE government: "Nothing is the PSD's definition after two years of government, they promised and what did they do? Nothing, that's what a courageous citizen from Suceava called to Liviu Dragnea, directly from the middle of a PSD supporters' rally. We continue to show the government of nothing, with people of nothingness. We show what they have not done what they should have done for Romania. What did they do for the railway infrastructure? Nothing to make CFR more efficient, losses of 300 million a year. Nothing to reduce train delays, no major modernization project has been launched. Nothing to ensure the safety of travelers, citizens are still circulating in old wagons. The list of things is long because nothing was more important to the PSD than to escape jail thieves". The post generated 5.044 likes, 34 love, 263 haha, 37 wow, 74 sets, 960 angry 1.127 comments and 1.335 shares.

\section{4}

\section{Conclusions}

At the European Parliamentary elections in Romania, the polling presence was $49.02 \%$ (8.954.959 voters). Of the total voters, $51.2 \%$ are women, and $48.8 \%$ are men. At the same time, $57.4 \%$ of voters come from urban areas, and $42.6 \%$ come from rural areas. It should be mentioned that the majority of Internet users in Romania come from urban areas. In terms of age categories, we note the following: 18-24 (8.29\%), 25-34 (15.15\%), 35-44 $(18.70 \%), 45-64(37.47 \%)$ and $65+(20.44 \%)$. The final results ${ }^{1}$ of the European Parliamentary elections in Romania - 2019 show that the National Liberal Party won the elections with $27.0 \%$ of the votes, the Social Democratic Party was second with $22.5 \%$ of votes, and USR-PLUS achieved an electoral score of $22.4 \%$.

\footnotetext{
${ }^{1}$ https://prezenta.bec.ro/europarlamentare26052019/romania-pv-final
} 
The National Liberal Party managed to mobilize the electorate in Social Media much better than its counter-candidates. At the end of the electoral campaign, PNL had 293,677 Facebook fans, 2.32 times more than USR and 3.39 times more fans than PSD. Meanwhile, The Liberal Party obtained $72.9 \%$ of all reactions, comments and shares, having the highest rate of engagement among users. Between May 6, 2019 - May 13, 2019, the National Liberal Party's engagement rate increased considerably, from $9.4 \%$ to $19 \%$, while counter-candidates maintained this indicator at $6.8 \%$ (USR) and between $2.9 \%$ and $7.2 \%$ (PSD). Even at the frequency of posting, PNL was the leader, with 7.66 posts per day during the election campaign, compared to USR (5.28 posts per day) and PSD (1.28 posts per day).

The National Liberal Party has focused its communication strategy, mostly on statements by the candidates and the President of Romania, Klaus Iohannis, on how this party will get involved in people's lives if it wins the elections. On the other hand, PSD focused its communication strategy on long videos (between 45 and 54 minutes) with electoral events organized by party supporters and party chairman Liviu Dragnea's statements or postings highlighting the main achievements of the PSD Government in the field agriculture. The key messages of the USR centered on attacks on the Social Democratic Party, presenting PSD leaders and their weak activities as governors.

The National Liberal Party succeeded in winning elections because communication strategies have mobilized Facebook fans to interact and distribute electoral information to many social groups. On the other hand, USR managed to get a very good election score because it managed to mobilize in Social Media users who absent in the last elections. Beyond the poorer percentage compared to other elections, PSD has kept its traditional number of votes, but lost elections because opposition parties (PNL and USR) managed to mobilize through Facebook segments of uninterested public of political subjects or who wanted to vote against the party in the government (PSD). In the 2019 European Parliament elections, Facebook has played a decisive role, and parties that have better understood how to mobilize their audience have won the cause.

5 References

[1] *** Institute for Politics, Democracy and Internet. (2004). Political Influentials Online in the 2004 Presidential Campaign. Washington .D.C.: The Graduate School of Political Managment, The George Washington University.

[2] Granovetter, M. (1973). "The Strength of Weak Ties". American Journal of Sociology 78(6). Chicago: University of Chicago Press, $1360-1380$.

[3] Tasente, T. (2014). Comunicarea politică prin Social Media și reacțiile publicului online. Bucharest: Editura Universitară. 